\title{
Pressure Characteristics of Gas and Liquid Flow inside the Tube with Smaller Diameter
}

\author{
正 朱 寧（静岡理工科大学） ○高 宇（静岡理工科大学大学院）
}

\begin{abstract}
Ning ZHU, Shizuoka Institute of Science and Technology, 2200-2 Toyosawa, Fukuroi, Shizuoka, 437-8555, Japan
\end{abstract}
Yu GAO, Graduate School of Shizuoka Institute of Science and Technology

\section{1. 緒論}

近年、熱交換器の分野において、省スペース化、コンパク 卜化、高性能化、高効率化などが求めるなか、設計上、内径 が数 $\mathrm{mm}$ の細い配管がよく使用されるようになっている。

小口径配管内の流れでは、界面張力の影響で、その流動特 性および伝熱特性が通常の流路と異なる可能性がある。とく に、小口径配管内を流れる相変換を伴う流れでは、その流動 伝熱特性がさらに複雑なものとなる。これまでに、熱交換器 の設計に際し、通常の流路に関する経験式が用いられてきた が、細い配管を用いる設計では、新しい実験式に関する提案 が必要である。

本研究は、細い配管における気液二相流の流動特性を明ら かにすることを目的とする。研究では、まず、気液二相流の 圧力損失测定実験システムを構築する。続いて二相流におけ る圧力損出を計測定するとともに、可視化の実験を行う。最 後に、摩擦損失勾配とクオリティとの関係を整理する。

\section{2. 実験}

Fig. 1 に気液二相流圧力損失測定実験システムの概略図を 示す。水平状に設置したテストセクションは全長 $1500 \mathrm{~mm}$ 、外 径 $6 \mathrm{~mm}$ 、内径 $3 \mathrm{~mm}$ の細い配管とする。

二つのポンプを使って、それぞれ一定流量の水と空気を流 路に供給する。混合器では、異なる流量の水と流量を混合し てからテストセクションを通過させる。テストセクションの

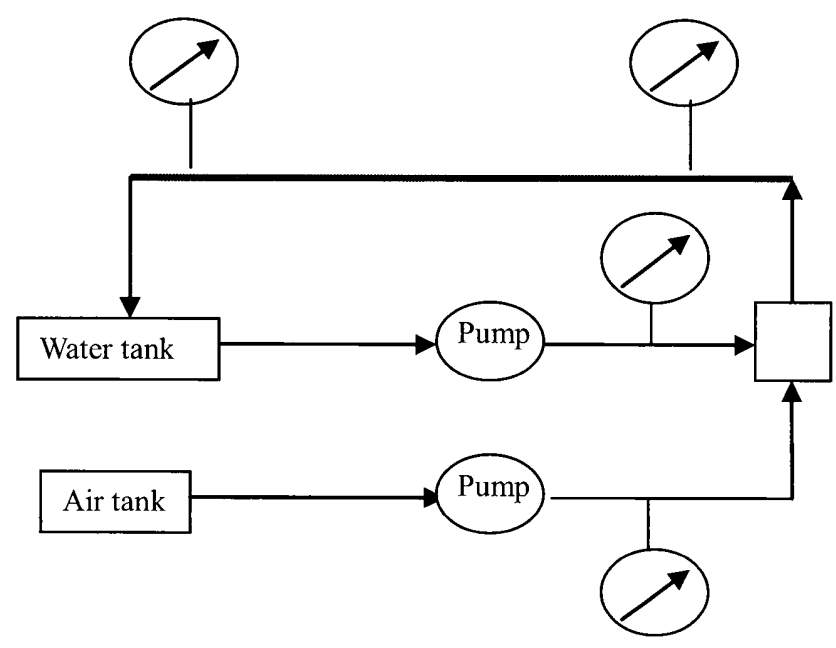

Fig.1 Experiment system for measuring pressure drop inside the tube for gas and liquid flow
前後に設置した圧力計により圧力損失を測定する。一方、水 と空気の流量は流量計によりそれぞれ測定される。

一方、可視化実験、気液二相流圧力損失を測定する実験の システムを活かし、テストセクションでは、透明なチューブ を設置する。観察のため、水に少量な油性顔料を混入する。 ほかの流動条件は上述したもの一致する。

3. 結果と考察

3-1 細い配管内の圧力損失

流路断面の気相及び液相流量を $\mathrm{m}_{\mathrm{g}}, \mathrm{m}_{\mathrm{l}}$ とすると、気相と液 相の質量速度はそれぞれ式（1）に示す。

$$
\mathrm{G}_{\mathrm{g}}=\mathrm{m}_{\mathrm{g}} / \mathrm{A} \quad, \mathrm{G}_{\mathrm{l}}=\mathrm{m}_{\mathrm{l}} / \mathrm{A}
$$

クオリティの計算式は式 (2) に示す。

$$
\mathrm{x}=\frac{\mathrm{G}_{\mathrm{g}}}{\mathrm{G}_{\mathrm{g}}+\mathrm{G}_{\mathrm{l}}}=\mathrm{G}_{\mathrm{g}} / \mathrm{G}
$$

実験では、空気コンプレッサの出口圧力を $1 \mathrm{Mpa}$ と $1.5 \mathrm{Mpa}$ 、 水の流量を $1 \times 10^{-3} \mathrm{~kg} / \mathrm{s} \sim 6.06 \times 10^{-3} \mathrm{~kg} / \mathrm{s}$ とし、測定したテス トセクションの圧力損失とクオリティの関係を Fig. 2 に示す。 Fig. 2 からは、まず、供給気圧が $0.15 \mathrm{Mpa}$ 時の圧力損失は $0.1 \mathrm{Mpa}$ 時の圧力損失より大きいことが分かった。続いて、ク オリティが大きくなるにつれ、压力損失も大きくなることが 確認できた。

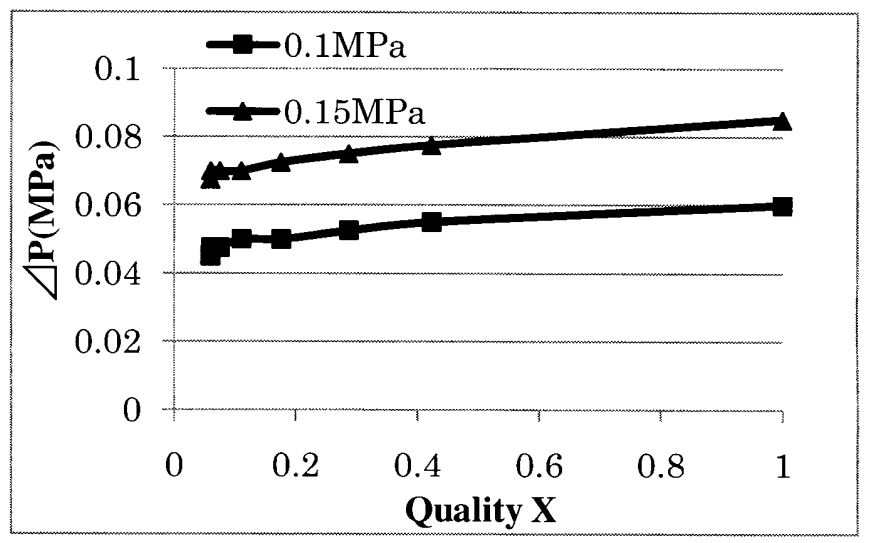

Fig.2 Relation between quality and pressure drop 


\section{3-2 可視化実験の結果}

Fig. 3 には可視化実験（空気コンプレッサの出口圧力を 1Mpa）の結果を示す。左から右へ水の流量がそれぞれ Qg=1 $\times 10^{-3} \mathrm{~kg} / \mathrm{s} 、 Q \mathrm{~g}=3.97 \times 10^{-3} \mathrm{~kg} / \mathrm{s} 、 Q \mathrm{~g}=6.06 \times 10^{-3} \mathrm{~kg} / \mathrm{s}$ とすると き、透明なパイプを流れる二相流は、いずれも波状流として、 上部では、空気が、下部では水が流れていることを確認した。 とくに、空気と水の境界面のところでは、波が打つ様子も確 認できた。波状流の流動様式を Fig. 4 に示寸。

\section{3-3 摩擦損失勾配との関係}

可視化実験の結果を踏まえ、波状流として摩擦損失勾配と クオリティの関係を整理する。圧力損失の推算式としては極 めて多数のものが提案されているが ${ }^{(1-4)}$ 、本研究では、均質流 モデルを用いることにした。

気液二相流において気液速度比スリップ $\mathrm{S}=1$ つまり両相 間の相対速度を無視すると、流れは単相流の式と全く同じ形 で表示できることになる。均質流モデルに基づいて全流量が 液相状態で流れた時の摩擦損失こう配は計算式（3）を示す。

$$
\left(\frac{\Delta \mathrm{P}}{\Delta \mathrm{Z}}\right)_{\mathrm{Lo}}=\frac{2 \int_{\mathrm{L}}}{\mathrm{D}} \mathrm{G}^{2} v_{\mathrm{I}}
$$

同様に、均質二相流の摩擦損失こう配は計算式（4）で与 えられる。

$$
\left(\frac{\Delta \mathrm{P}}{\Delta \mathrm{z}}\right)_{\mathrm{TPF}}=\frac{2 \mathrm{f}_{\mathrm{TP}}}{\mathrm{D}} \mathrm{G}^{2}\left[v_{\mathrm{l}}+\mathrm{x}\left(v_{\mathrm{g}}-v_{l}\right)\right]
$$

二相流の摩擦係数を液単相流の場合と同様に、計算式 ( 5 ) とおき、

$$
f_{\mathrm{TP}}=0.079(\mathrm{GD} / \eta)^{-1 / 4}
$$

とおくと、摩擦損失勾配比は式（6）で表わされる。

$$
\begin{aligned}
\Phi_{\mathrm{Lo}}^{2} & =\left(\frac{\Delta \mathrm{P}}{\Delta \mathrm{z}}\right)_{\mathrm{TPF}} /\left(\frac{\Delta \mathrm{P}}{\Delta \mathrm{z}}\right)_{\mathrm{Lo}} \\
& =\left[1+\mathrm{x}\left(\frac{v_{\mathrm{g}}-v_{1}}{v_{\mathrm{I}}}\right)\right]\left[1+\mathrm{x}\left(\frac{\eta_{\mathrm{I}}}{\eta_{\mathrm{g}}}-1\right)\right]^{-1 / 4}
\end{aligned}
$$

ここで、Lは液相、vは比容積、D は管径、 $f_{\mathrm{T} P}$ は二相流摩 擦係数、 $\eta$ は粘度、 $\mathrm{x}$ はクオリティとする。

実験条件により算出したクオリティを横軸に、式 6 により 算出した摩擦損失勾配、あわせて実際に測定した摩擦損失勾 配を Fig. 5 に示した。

Fig. 5 では、クオリティが大きくなるにつれ、均質流モデ ルに基づく摩擦損失勾配も実際に測定した摩擦損失勾配も大 きくなっていくことが分かった。しかし、均質流モデルによ る計算值に比べて、実際に測定した摩擦損失勾配が低かった。
それは、表面張力の影響によるものかはまだ未明であり、引 き続き調査して行く必要があると思われる。

6. 結論

（1）気液二相流の圧力損失測定システムを構築した。

（2）気液二相流の圧力損失を測定した結果、クオリティが 増加するにつれ圧力損失が増大する。

（3）摩擦損失勾配もクオリティの増加に伴い増大すること が分かった。

7. 参考文献

(1) 平田哲夫、岩田博、田中誠、石川正昭、西田耕作、基礎加 らの冷凍空調、森北出版 (2007)

(2) 赤川浩爾、藤田達夫、気液二相流、株式会社 コロナ社出 版 (1974)

（3）日本機会学会、気液二相流技術ハンドブック 株式会社 コロナ社出版（2006）

（4）日本機会学会、伝熱工学資料、丸善株式会社（1986）

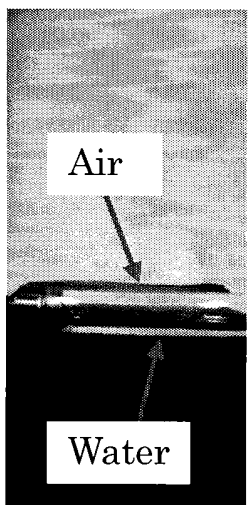

$\mathrm{Qg}=1 \times 10^{-3} \mathrm{~kg} / \mathrm{s}$

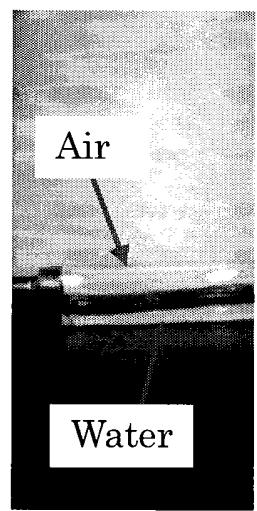

$\mathrm{Qg}=3.97 \times 10^{-3} \mathrm{~kg} / \mathrm{s}$

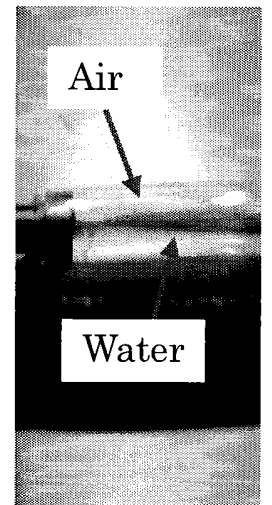

$Q g=6.06 \times 10^{-3} \mathrm{~kg} / \mathrm{s}$
Fig.3 Result of flow pattern

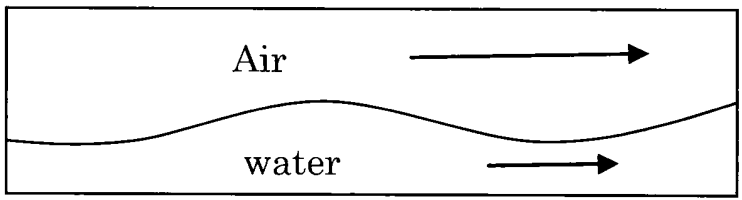

Fig.4 Wavy flow

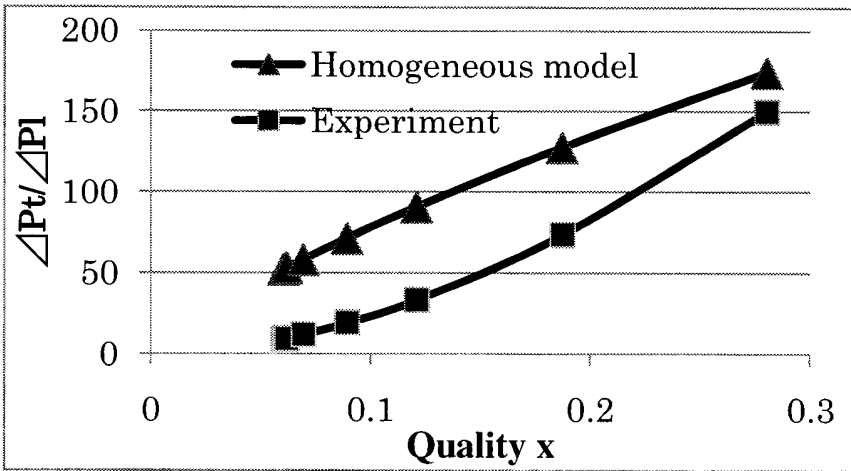

Fig.5 Relation between friction drop gradient and quality $\left(\mathrm{Qg}=3.9 \times 10^{-4} \mathrm{~kg} / \mathrm{s}\right)$ 